Ambiente \& Água - An Interdisciplinary Journal of Applied Science
ISSN 1980-993X - doi:10.4136/1980-993X
www.ambi-agua.net
E-mail: ambi.agua@gmail.com

\title{
Land-use change effect on the hydro-dynamic characteristics of soil in the Brazilian semi-arid region
}

ARTICLES doi:10.4136/ambi-agua.2368

Received: 16 Jan. 2019; Accepted: 06 Feb. 2020

\section{Willames Albuquerque Soares ${ }^{1 *}$; Simone Rosa da Silva2 ${ }^{2}$; José Romualdo de Sousa Lima ${ }^{3}$ iD}

\footnotetext{
${ }^{1}$ Departamento de Física de Materiais. Escola Politécnica de Pernambuco. Universidade de Pernambuco (UPE), Rua Benfica, $n^{\circ}$ 455, CEP: 50720-001, Recife, PE, Brazil

${ }^{2}$ Departamento de Engenharia Civil. Escola Politécnica de Pernambuco. Universidade de Pernambuco (UPE), Rua Benfica, n 455, CEP: 50720-001, Recife, PE, Brazil. E-mail: simonerosa@ poli.br

${ }^{3}$ Unidade Acadêmica de Garanhuns. Universidade Federal Rural de Pernambuco (UFRPE), Avenida Bom Pastor, s/n, CEP: 55292-278, Garanhuns, PE, Brazil. E-mail: jose.romualdo@pq.cnpq.br

*Corresponding author. E-mail: was@poli.br
}

\begin{abstract}
The search for better living conditions has led the residents of the Brazilian semi-arid region to plant forage crops, leading to a gradual decrease in the native vegetation (Caatinga) of this region. The effects caused by the replacement of Caatinga with palm, for example, have been little studied, especially with regard to the physical and hydraulic properties of the soil. The objective of this study was to compare the physical-hydraulic characteristics of a litholic neosol in two areas having different vegetation cover: one area cultivated with forage palm $(O$. ficus-indica) and the other covered by native Caatinga. Differences in soil structure, especially in porosity, between the natural and cultivated soils were observed to control the hydrodynamic processes, resulting in changes in water retention curves and hydraulic conductivity. Natural soil presents low values of hydraulic conductivity when compared to those of cultivated soil. This increase is probably due to soil management required for forage palm cultivation. The natural soil structure, characterized by relatively low saturated hydraulic conductivity values, presents an infiltrability that favors surface runoff. Human activities in the study area have promoted changes in the soil's physical attributes, decreasing density and increasing porosity. Consequently, there is an increase in water infiltration into the soil and a reduction of runoff in cultivated areas, confirming results obtained in previous studies.
\end{abstract}

Keywords: forage palm, infiltration, weibull distribution.

\section{Efeito da mudança no uso do solo nas características hidrodinâmicas do solo no semiárido Brasileiro}

\section{RESUMO}

A busca por melhores condições de vida tem levado os moradores da região semiárida brasileira a optarem por plantar culturas forrageiras, provocando a diminuição gradativa da vegetação nativa (Caatinga) desta região. A substituição da Caatinga pela palma, por exemplo, tem efeito pouco estudado, sobretudo no tocante as propriedades físico-hídricas do solo. $\mathrm{O}$ objetivo deste estudo foi comparar as características físico-hídricas de um Neossolo Litólico 
em duas áreas com diferentes condições de cobertura vegetal: uma cultivada com Palma forrageira (O. ficus-indica) e a outra com Caatinga. Observou-se que as diferenças na estrutura do solo, especialmente na porosidade, entre o solo natural e cultivado, controlam os processos hidrodinâmicos, resultando em alterações nas curvas de retenção de água no solo e de condutividade hidráulica. O solo natural apresentou uma baixa condutividade hidráulica, quando comparada a determinada para o solo cultivado. Esse aumento deve-se provavelmente ao manejo do solo, necessários para o cultivo da palma forrageira. A estrutura do solo natural, caracterizada por valores relativamente baixos de condutividade hidráulica saturada, apresentam uma infiltrabilidade que favorece o escoamento superficial. A antropização do solo na área em estudo promoveu alterações nos atributos físicos dos solos, diminuindo a densidade e aumentando a porosidade. Consequentemente há o aumento da infiltração de água no solo e a redução do escoamento superficial no solo cultivado, corroborando com resultados obtidos em estudos anteriores.

Palavras-chave: infiltração, palma forrageira, semiárido, weibull.

\section{INTRODUCTION}

Steppe Savanna, or Caatinga, covers about $10 \%$ of the total Brazilian territory, an area of 734 thousand $\mathrm{km}^{2}$, and is found mainly in the Northeast Region. It is often marked by two annual dry periods: one long, followed by intermittent rains, and another short, which can become torrentially rainy.

The Caatinga has been strongly affected by anthropic action. About $80 \%$ of its original ecosystem has already been altered by human processes, mainly through fire and deforestation, practices still common when preparing the soil for agriculture. In addition to destroying vegetation cover, these actions can drastically reduce wildlife populations, affect water quality and disrupt the climate balance and soil balance.

Caatinga soils usually have a superficial crust in areas without vegetation which, together with the textural difference between horizons, directly influence the infiltration of water, accentuating the water deficit and causing the few existing plant species in the area to be those that have adapted most fully to this condition (Souza et al., 2016).

The root system plays an important role in the infiltration process. Pinheiro et al. (2013) observed that the root system of Caatinga vegetation ranges from $0.60 \mathrm{~m}$ to $0.78 \mathrm{~m}$ in depth in non-restrictive soils and that the depth of the roots during the dry season is, on average, $10 \mathrm{~cm}$ less than during the rainy season. This fact indicates an adaptation strategy and generates secondary porosity of the soil in order to increase the infiltration of water into the root zone. However, crops lead to modifications to the soil attributes depending on the intensity of soil preparation and the type of management used.

Well-adapted to the conditions in the semi-arid region of Pernambuco, forage palm (Opuntia ficus-indica) was introduced into Brazil at the end of the 19th century and is the xerophytic agricultural option with the greatest potential in the Northeast, surpassing 400,000 hectares. It has been used for years as feed for cattle herds during the dry season, mainly due to its high potential for phytomass production. The requirements for forage palm cultivation, such as climatic conditions, soil texture varying from sandy to clayey, and the variation between nocturnal and diurnal temperatures are all found in Northeast Brazil (Edivani et al., 2013).

Genin et al. (2017) evaluated the natural regeneration of argania (Argania spinosa) and palm fruit production (Opuntia fícus-indica) in the arid pre-Saharan zone of south-west Morocco. They observed that the perennial planting of palm allied with the exclusion of pasture for cattle, creates conditions favorable for forest recovery. They also point out that these synergies could be a basis for promoting sustainable development and ecological restoration, 
as well as inspiring alternative guidelines for more integrated plans that combat desertification.

Oliveira Junior et al. (2014) evaluated the impact of pasture on the hydrodynamic properties of a regolithic neo-soil in the Agreste Region of Pernambuco, and observed that the use of the soil for pastureland significantly altered its properties when compared with those of the natural Caatinga soil, mainly with regard to soil density and hydraulic conductivity.

Infiltration in semi-arid areas is often limited by low hydraulic conductivity and extreme levels of water repellency which, when combined with a high intensity of precipitation, results in excess infiltration as a dominant surface runoff mechanism. Farrick and Branfireun (2014), when studying dry tropical forests, found hydraulic conductivity values between 9 and $164 \mathrm{~mm}$ $\mathrm{h}^{-1}$, greater than rainfall intensity for more than $75 \%$ of rain events. They also observed that $70 \%$ of the infiltrated water is contained in the upper $30 \mathrm{~cm}$ of soil.

Kargas et al. (2012) assessed the effects of surface conditions on water infiltration into the soil in semi-arid climates in Greece and concluded that cultivation reduces bulk soil density, resulting in changes to the water retention curve in soil and in saturated hydraulic conductivity.

Leite et al. (2018) studied the hydrodynamic behavior of the Brazilian Caatinga in four stages of degradation. They noticed that the infiltration of water into the soil was lower than the saturated hydraulic conductivity and associate this fact to the soil slope generated by the impact of the rain. They also observed that the growth of the Caatinga promotes the recovery of the hydraulic properties of the soil, increasing saturated hydraulic conductivity and infiltration.

Mendonça et al. (2009), studying the infiltration of water in a clayey yellow red latosol located in the Araripe Plateau in Ceará, observed that the litter and organic matter produced by the native forest protect the soil from rainfall impact and help maintain a high infiltration capacity when compared to deforested areas.

Soares (2018a) estimated different rainfall events in order to analyze the effect of precipitation intensity on soil/water dynamics in the semi-arid region of Brazil. He noted that the hydrodynamic characteristics of the natural soil where Caatinga is found cause the upper 40 centimeters to retain most of the precipitated water. By altering the physical characteristics of the soil of the region, infiltration increases and water is retained at a greater depth, so that the native vegetation cannot absorb the stored water.

Soil use and management impact its physical quality, mainly soil aeration. However, it also makes the soil susceptible to erosion above all for monocultures (Lima et al., 2018). Replacing native vegetation by forage palm crop, due to soil management necessary for cultivation, modifies the physical properties of the soil in ways that can make restoration of native forest impossible (Soares, 2018b).

Due to the variability in the magnitude of responses to changes in soil use and soil cover, site-specific studies are needed in order to understand the influences caused by soil cover changes in semi-arid environments (Owuor et al., 2016). However, few studies have evaluated the hydrodynamic behavior of the Caatinga vegetation compared to other crops. This study therefore sought to compare the hydraulic characteristics of a litholic neosol in two areas having different vegetative cover: one cultivated with forage palm (O. ficus-indica) and the other with native Caatinga. The hydrodynamic characteristics of the soil were determined using threedimensional infiltration tests and by analyzing the soil granulometry.

\section{MATERIALS AND METHODS}

\subsection{Study location}

The study was conducted in the municipality of São Bento do Una, Pernambuco, in the southern Agreste mesoregion (geographical coordinates: $8^{\circ} 36^{\prime} 37^{\prime \prime} \mathrm{S}$ by $36^{\circ} 21^{\prime} 45^{\prime \prime} \mathrm{W}$ at approximately $621 \mathrm{~m}$ altitude, Figure 1) from April to June 2017. The plots consisted of 2.0 ha of natural soil, where the Caatinga vegetation is preexistent, and 4.5 ha of soil cultivated with 
forage palm (O. ficus-indica). The soil of the study area is classified as a litholic neosol with local relief characterized as gently undulated with an average slope of $1.6 \%$. The predominant climate is semi-arid with a hot and dry summer and a rainy season between the months of April and June. The climate is classified as BSh according to the Köppen-Geiger classification scheme. The mean annual precipitation does not exceed $300 \mathrm{~mm}$ and the natural vegetation is composed of hyper xerophilic Caatinga.

According to local residents, some more than 90 years old, the Caatinga vegetation of this plot has never been deforested. The most common shrubs are Black Jurema (Mimosa hostilis Benth.), White Jurema (Mimosa hostilis) and the more rare Umbuzeiro (Spondias tuberosa). Among the cacti found, the most notable are the Foxtail (Harrisia adscendens), Facheiro (Pilosocereus catingicola), Mandacaru (Cereus jamacaru), and Xique-xique (Pilosocereus gounellei). Due to a severe dry period, the caatinga was found to be noticeably degraded, resembling an area studied by Leite et al. (2018) that had been deforested and recovered 35 years ago.

In the plot where the native vegetation has been replaced by forage palm (O. ficus-indica) for at least 30 years, the soil is turned by machinery, while planting and organic fertilization are performed manually, the latter occurring twice during each crop cycle, once during planting and once at one year. In both cases, approximately $3 \mathrm{t} \mathrm{ha}^{-1}$ is used. Non-deformed soil samples were collected from the 0-20 cm depth layer in two distinct areas: under Caatinga and under forage palm (O. ficus-indica). In order to determine the hydrodynamic properties of the soil, granulometry and infiltration tests were carried out at both sites.

In Figure 1b, we can see a stretch of the 2 ha of Caatinga. Although the plants are xerophiles, the scarcity of rainfall over the last five years has drastically reduced their vegetative density.In this area, the predominant arboreal vegetation is composed mainly of black jurema (Mimosa hostilis Benth.), white jurema (Mimosa hostilis) and more rarely umbuzeiro (Spondias tuberosa). Among the cacti found were the foxtail (Harrisia adscendens), the woodpecker (Pilosocereus catingicola), the mandacaru (Cereus jamacaru) and the xique-xique (Pilosocereus gounellei). The soil is compacted, shallow, and stony, with fragments of rock on the surface. At a depth of $0.4 \mathrm{~m}$, it becomes impossible to excavate without the use of machinery, due to the large quantity of rocks.

In Figure 1c, the 4.5 ha of soil cultivated with spineless cactus (O. ficus-indica) is shown. Along with the cultivation, a large and diverse amount of weeds can be seen, which are periodically removed. Due to the scarcity of water, the crop does not grow satisfactorily. The leaves are small, twisted, and largely a non-characteristic color with a yellowish tint. Fertilization is carried out at the beginning of planting and is not repeated until the time of harvest. Initially, the distance between plants is approximately $0.5 \mathrm{~m}$. Between lines, the distance is about $1.0 \mathrm{~m}$. Both distances decrease as the crop grows. Due to the treatment necessary for cultivation, the soil is not compacted nor does it contain rocky fragments within the upper $0.4 \mathrm{~m}$ of its depth.

From April 1st to June 30th, 2017, a total of rainfall of $543.6 \mathrm{~mm}$, and its distribution is irregular throughout the period. Of the 91 days of study, 30 had no rainfall. In 44 days, precipitation occurred up to $10 \mathrm{~mm}$ and only in 17 days had precipitation greater than $10 \mathrm{~mm}$. The biggest rain event $(74.6 \mathrm{~mm}$ ) occurred on $05 / 28 / 2017$ (Figure 2). That is, the rains were of low intensity but with high frequency. 


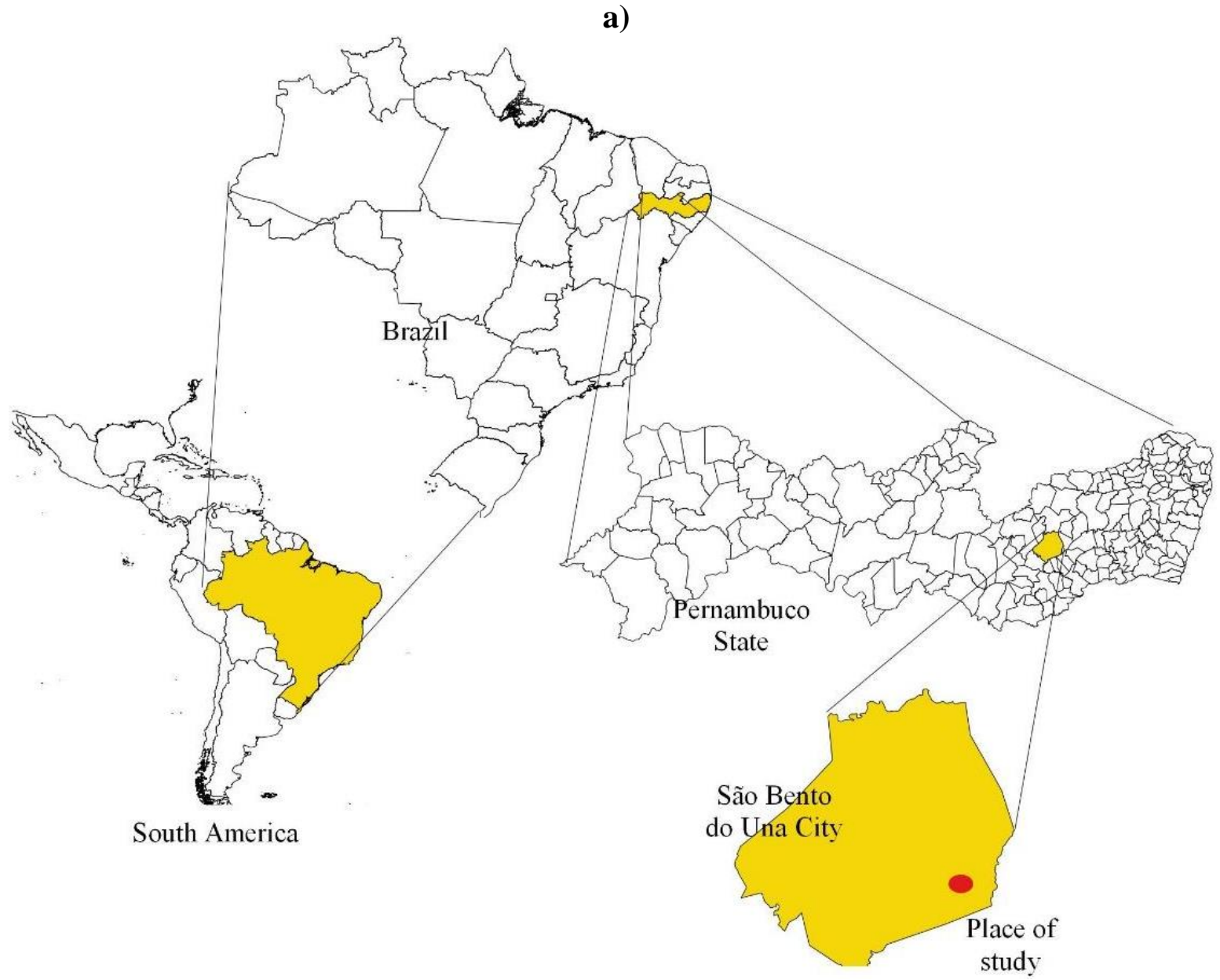

b)

c)

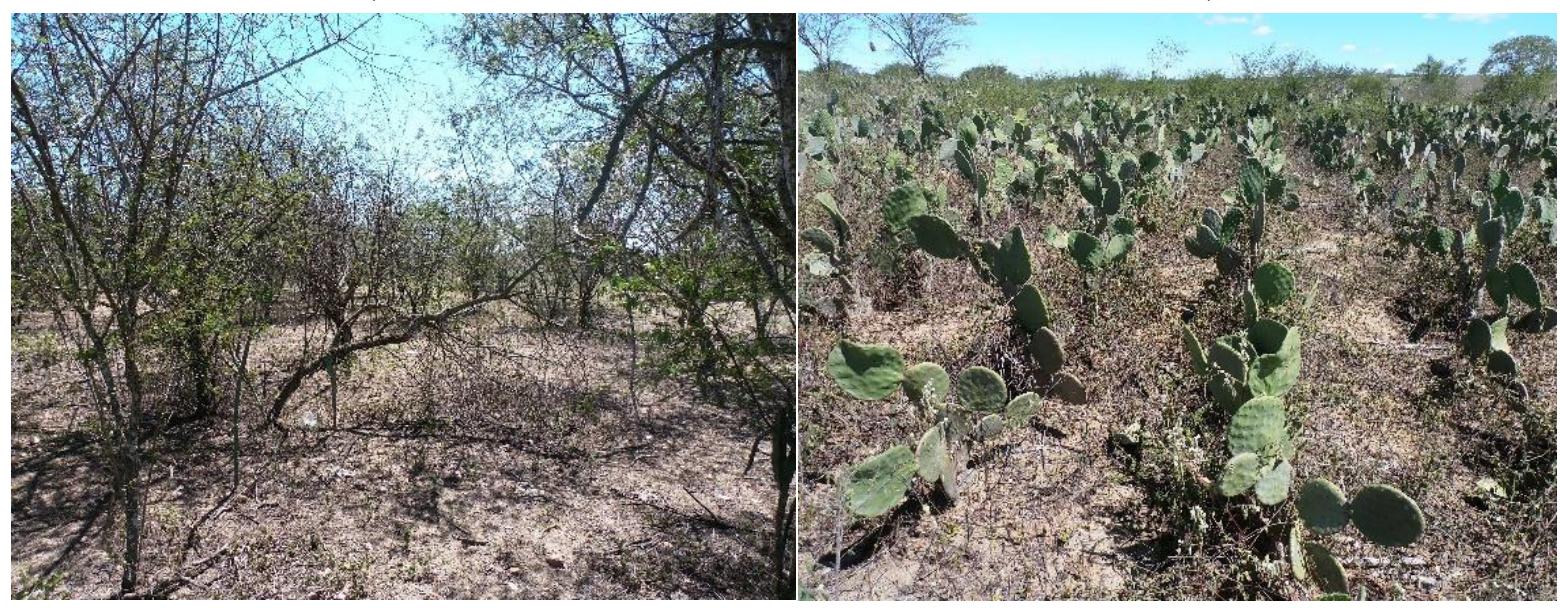

Figure 1. a) Localization map of the study region. b) Caatinga found in the study area. c) Spineless cactus (O. Ficus-Indica) cultivation in the study area. 


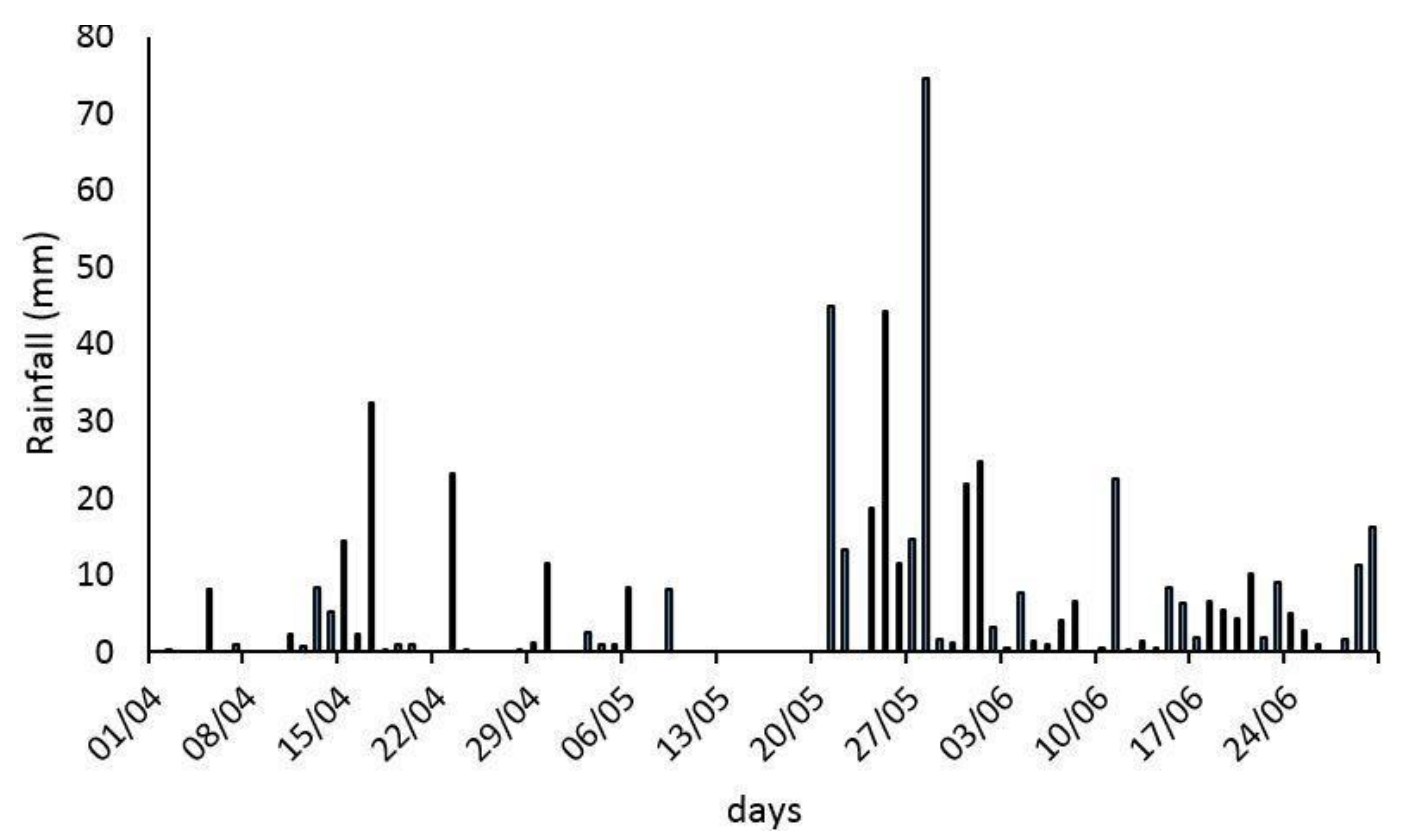

Figure 2. Rainfall from April 1st to June 30th, 2017.

\subsection{Granulometric tests}

The granulometric analysis was performed using the ABNT (2016) method, which makes it possible to determine the diameters of the finer particles (clay and silt) through sedimentation and the coarser ones (sand) through sieving. A sigmoid curve with asymptotic limits and an exponential growth rate, proposed by Weibull, with three adjustment parameters $\left(d_{m}, \beta\right.$ and $\left.\delta\right)$, was fitted to the points obtained from the particle size test Equation 1:

$F_{d}=100-\left(100-d_{m}\right) e^{-\beta d^{\delta}}$

Where $d$ is the particle diameter $(\mathrm{mm})$, and $F_{d}$ is the percentage of particles smaller or equal to $d$. The adjustment parameters to fit the model to the known points of the particle size distribution curve were determined optimally, considering as a criterion the minimization of an object function Equation 2:

$$
F O=\sum_{i=1}^{N}[x(i)-\hat{x}(i)]^{2}
$$

Where $x(i), \hat{x}(i)$ are the measured and calculated values of the accumulated fractions, for the respective fraction $i$. From the fitted grain-size curves, the water retention curve was estimated using the model proposed by Arya and Heitman (2015), which calculates the values of moisture and matric potential from the values for particle diameter and concentration obtained through the granulometric analysis.

The water content in the soil was estimated from the particle size distribution, as a contribution of each fraction to the wetting of the soil, using the Equation 3:

$\theta_{i}=\phi \sum_{i=0}^{i} w_{i}$

Where $\varphi$ represents the porosity $\left(\mathrm{m}^{3} \cdot \mathrm{m}^{-3}\right), \mathrm{w}_{i}$ is the mass fraction of $i\left(\mathrm{~kg} \mathrm{~kg}^{-1}\right)$, calculated by means of a sigmoidal function fitted to the soil particle size distribution data. The soil matric potential $\left(h_{i}\right)$ was calculated from the capillarity and from the pore radius (Equation 4): 


$$
h_{i}=\frac{2 \sigma}{\rho_{w} g \sqrt{\frac{0.717 \Phi\left(w_{i} / p_{b}\right)}{\left(\frac{3 w_{i}}{4 \pi R_{i}^{3} p_{p}}\right)^{4 / 3} R_{i}}}}
$$

Where $\sigma$ is the surface tension at the air-water interface $\left(0.0728 \mathrm{~N} \mathrm{~m}^{-1}\right), g$ is the acceleration of gravity $\left(9.81 \mathrm{~m} \mathrm{~s}^{-2}\right), R_{i}$ is the radius of the particles, and $\rho_{w}, p_{p}$, and $p_{b}$ are the densities of water, apparent soil, and particles $\left(\mathrm{kg} \mathrm{m}^{-3}\right)$. This methodology has been well evaluated for Brazilian soils (Soares and Hammecker, 2017).

\subsection{Infiltration tests}

Simple-ring infiltrators with a diameter of $150 \mathrm{~mm}$ and height of approximately eight centimeters were used in the infiltration tests. In order to minimize the structural disturbance and ensure a vertical flow on the soil surface, they were embedded about one centimeter into the soil.

According to the applied methodology, undeformed samples were collected to determine the soil density (using an Uhland auger) and deformed samples to determine the initial and final volumetric contents of water and to obtain the granulometric curve.

A fixed volume of water was then poured into the cylinder at time zero: the elapsed time during infiltration of the known water volume could thus be measured. Once the initial volume had been completely infiltrated, a second known volume of water was added to the cylinder, and the time required to infiltrate was measured. This procedure was repeated for a series of volumes to reach steady state.

The three-dimensional infiltration of water into the soil was modeled using the analytical equation for long times proposed by Haverkamp et al. (1994) in order to obtain the saturated hydraulic conductivity $\left(K_{s}\right)$ and the sorptivity $(\mathrm{S})$.

The simplified form of this Equation 5 is defined by:

$I_{3 D}=\left[K_{S}+\frac{\gamma S^{2}}{r_{d}\left(\theta_{0}-\theta_{n}\right)}\right] t+\frac{S^{2}}{2\left(K_{S}-K_{n}\right)(1-\beta)} \ln \left(\frac{1}{\beta}\right)$

Where $I_{3 D}$ is the three-dimensional infiltration, $\theta_{n}$ and $\theta_{0}$ are the initial and final humidities $\left(\mathrm{mm}^{3} \cdot \mathrm{mm}^{-3}\right), r_{d}$ is the infiltrator radius $(\mathrm{mm}), t$ is the time $(\mathrm{s}), K_{n}$ is the hydraulic conductivity at the start of the test $\left(\mathrm{mm} \mathrm{s}^{-1}\right)$, and $\gamma$ and $\beta$ are dimensionless parameters.

Capillarity and gravity affect three-dimensional infiltration. This influence can be estimated through the capillary length scale, $\lambda_{C}$ (White and Sully, 1987) and the characteristic radius of hydraulically active pores, $\lambda_{m}$ (Philip, 1987), determined by Equations 6 and 7:

$$
\begin{aligned}
& \lambda_{c}=\frac{\delta S^{2}}{\left(\theta_{f}-\theta_{i}\right) K_{s}} \\
& \lambda_{m}=\frac{\sigma}{\rho_{w} g \lambda_{c}}
\end{aligned}
$$

Where $\sigma$ is surface tension of water $\left(0.0728 \mathrm{~N} \mathrm{~m}^{-1}\right), \rho_{w}$ is the specific mass of water $\left(103 \mathrm{~kg} \mathrm{~m}^{-3}\right), g$ is the acceleration of gravity $\left(9.81 \mathrm{~m} \mathrm{~s}^{-2}\right)$, and $\delta$ is the diffusivity shape parameter (0.55).

$\lambda_{C}$ represents the relative importance of capillary forces compared to gravity, when water is transmitted through the soil with initial moisture $\left(\theta_{i}\right)$, and $\lambda_{\mathrm{m}}$ defines the average size of the pores that participate in the infiltration process. The higher the $\lambda_{\mathrm{m}}$, the greater the effect of gravity compared to capillarity. 
Six point tests were performed in each of the plots, with three repetitions, totaling 36 samples. The simple-ring infiltrometer test is an excellent alternative considering attributes such as preparation and test execution costs, time required for its execution, and the fact that it has been used by various authors (Souza et al., 2016; Oliveira and Soares, 2017). A disadvantage of this infiltrator is that it does not characterize the surface sealing generated by the impact of rain drops.

\subsection{Hydrodynamic Characterization}

The results obtained for volumetric moisture $(\theta)$ and matric potential $(h)$ were fitted to the Equations 8 and 9 proposed by Van Genuchten (1980):

$$
\begin{aligned}
& \theta(h)=\theta_{r}+\frac{\theta_{s}-\theta_{r}}{\left[1+\left|\frac{h}{h_{g}}\right|^{n}\right]^{1-2 / n}} \\
& K(\theta)=K_{S}\left(\frac{\theta-\theta_{r}}{\theta_{s}-\theta_{r}}\right)^{0.5}\left[1-\left(1-\left(\frac{\theta-\theta_{r}}{\theta_{s}-\theta_{r}}\right)^{\frac{1}{1-2 / n}}\right)^{1-2 / n}\right]^{2}
\end{aligned}
$$

In this way, the values for residual $\left(\theta_{r}\right)$ and saturated $\left(\theta_{\mathrm{s}}\right)$ volumetric humidity, the pore size distribution index $(n)$, and the bubbling pressure $\left(h_{g}\right)$ were determined.

\subsection{Soil repellency to water}

In order to estimate the degree of soil repellency to water, the water droplet penetration time (WDPT) method was used, which consists of applying two drops of water (around $40 \mu \mathrm{l}$ ) with a Pasteur pipette, and then measuring the time taken for these drops to penetrate the sample. Ten point tests were performed in each of the plots, with three repetitions, totaling 60 samples.

\section{RESULTS AND DISCUSSION}

\subsection{Granulometry and infiltration tests}

From the sieving and sedimentation tests, it was possible to determine the granulometric fractions of the studied soils. For the natural soil, the average fractions of sand, silt, and clay were $72.13 \%, 17.24 \%$, and $10.63 \%$, respectively. For the cultivated soil, the average fractions of sand, silt, and clay were $68.19 \%, 16.71 \%$, and $15.10 \%$, respectively. The differences between these soils were not considered to be significant (t-test), and these soils were classified texturally as sandy loam (Table 1). These results were expected, as the original material was identical for the two classes of land use. In both cases, the amount of sand present is considerably higher than the clay and silt fractions.

Table 1. Granulometric fractions, density $(\rho)$, porosity $(\varphi)$, and water droplet penetration time (WDPT) of natural and cultivated soils.

\begin{tabular}{ccccccc}
\hline Soil & Clay (\%) & Silt $(\%)$ & Sand $(\%)$ & $\rho\left(\mathrm{g} \mathrm{cm}^{-3}\right)$ & $\varphi(\%)$ & WDPT(s) \\
\hline Natural & $10.63 \pm 3.2$ & $17.24 \pm 1.5$ & $72.13 \pm 2.6$ & $1.69 \pm 0.04$ & $36.23 \pm 3.7$ & $3.84 \pm 0.61$ \\
Cultivated & $15.10 \pm 2.7$ & $16.71 \pm 1.2$ & $68.19 \pm 3.1$ & $1.43 \pm 0.05$ & $46.04 \pm 3.2$ & $0.82 \pm 0.37$ \\
\hline
\end{tabular}

The similarity in soil textures is important because it suggests that possible differences in other physical and hydraulic properties (between natural and cultivated areas) can be attributed with some degree of confidence to the effects caused by use of the soil. The densities of the natural and cultivated soils were $1.69 \mathrm{~g} \mathrm{~cm}^{-3}$ and $1.43 \mathrm{~g} \mathrm{~cm}^{-3}$, respectively. Natural soil was expected to have a higher density, since the soil is plowed in preparation for planting the palms. 
Another fact that might contribute to higher compaction for the natural soil is its slope, which causes an increase in surface runoff. The slope of the natural soil was $1.6 \%$ while the portion of cultivated soil had a slope of only $1 \%$.

The values determined for the density are close to those found in other studies carried out in regions having the same characteristics. Rodrigues et al. (2016), found values between $1.46 \mathrm{~g} \mathrm{~cm}^{-3}$ and $1.61 \mathrm{~g} \mathrm{~cm}^{-3}$ for yellow argisol in a region of the Caatinga, in Juazeiro, BA. Oliveira Junior et al. (2014) observed values of $1.67 \mathrm{~g} \mathrm{~cm}^{-3}$ and $1.14 \mathrm{~g} \mathrm{~cm}^{-3}$ for natural regolithic neosol in the municipality of São João, PE, and $1.56 \mathrm{~g} \mathrm{~cm}^{-3}$ and $1.28 \mathrm{~g} \mathrm{~cm}^{-3}$ for soil planted with grass (Brachiaria decumbens Stapf).

Density directly affects soil porosity, retention, and conductivity (Kargas et al., 2012). There was an increase of approximately $27 \%$ in the porosity of the cultivated soil $(46.04 \%)$ compared to the natural soil $(36.23 \%)$. The same behavior was observed by Rodrigues et al. (2016), who found an increase of about $26 \%$ in yellow argisol in the municipality of Juazeiro, BA.

According to the classification by Bisdom, both soils present values that classify them as hydrophilic. However, it is worth mentioning that the values obtained for the natural soil were much higher than the values obtained for the cultivated soil. The highest WDPT values for the natural soil result from the higher concentration of fresh and/or partially decomposed matter, different from the organic matter found in the cultivated soil, which is already in an advanced state of decomposition.

The parameters for the grain-size curve proposed by Weibull (Equation 1) for natural and cultivated soils were adjusted appropriately, with an $\mathrm{r}^{2}$ greater than 0.99 . For the natural soil, the values of the parameters $d_{m}, \beta$ and $\delta$ were $10.62,2.53$, and 1.18 , respectively. For the cultivated soil, the values were $15.24,1.84$, and 1.52 . Although different, they are within the same order of magnitude and were able to efficiently fit to the measured data, with errors of less than $5 \%$.

From the field study, mean values were found for accumulated infiltration and the infiltration rate. In the natural soil, infiltration of $37.35 \mathrm{~mm}$ of water occurred after a time of $4489 \mathrm{~s}$. Initially, the infiltration rate was $0.027 \mathrm{~mm} \mathrm{~s}^{-1}$ and by the end of the test, the rate had fallen to $0.005 \mathrm{~mm} \mathrm{~s}^{-1}$. These values are different from those obtained for cultivated soil, which had a total infiltration of $87.15 \mathrm{~mm}$ in a time $1046 \mathrm{~s}$. At the start of the test, the infiltration rate was $0.231 \mathrm{~mm} \mathrm{~s}^{-1}$ and by the end of the test, it was $0.072 \mathrm{~mm} \mathrm{~s}^{-1}$. The water infiltration into the soil depends on porosity and on other factors that can interfere with soil pores, such as clay content, root systems, and initial moisture, among others (Pinheiro et al., 2013). As the initial moisture of both soils was practically the same $\left(0.04 \mathrm{~cm}^{3} . \mathrm{cm}^{-3}\right)$ and the amount of clay in the samples was not significantly different, the alterations in the infiltrated volumes result from the difference in porosity and in the repellency of water by the soil, which is higher for the Caatinga (Table 2).

Table 2. Adjustment parameters $\left(d_{m}, \beta, \delta\right)$, for the granulometric curves of natural and cultivated soils.

\begin{tabular}{ccccc}
\hline Soil & $d_{m}$ & $\beta$ & $\delta$ & Error $(\%)$ \\
\hline Natural & 10.62 & 2.53 & 1.18 & 1.23 \\
Cultivated & 15.24 & 1.84 & 1.52 & 3.03 \\
\hline
\end{tabular}

\subsection{Hydrodynamic characterization of the soil}

By fitting the van Genuchten equation (Equation 8) to the measured retention data, it was possible to estimate the values for bubbling pressure, the hydrodynamic parameters, and the residual and saturated volumetric moisture for both natural soil and cultivated soil (Table 3 ). The values found for all the parameters related to the natural soil were within the ranges 
determined by Oliveira Júnior et al. (2014), when comparing the hydrodynamic variability of soils with vegetation cover and with grass, in the semiarid region of Pernambuco.

Table 3. Bubble pressure $\left(h_{g}\right)$, hydrodynamic parameters ( $n$ and $m$ ), residual and saturated volumetric moisture $\left(\theta_{\mathrm{r}}\right.$ and $\left.\theta_{\mathrm{s}}\right)$, saturated hydraulic conductivity $\left(K_{s}\right)$, sorptivity $(S)$, capillary length scale $\left(\lambda_{C}\right)$, and characteristic pore radius $(\lambda m)$ for natural and cultivated soils.

\begin{tabular}{cccccccccc}
\hline Soil & $\begin{array}{c}\left|h_{g}\right| \\
(\mathrm{cm})\end{array}$ & $n$ & $m$ & $\begin{array}{c}\theta_{\mathrm{r}} \\
\left(\mathrm{cm}^{3} \mathrm{~cm}^{-3}\right)\end{array}$ & $\begin{array}{c}\theta_{\mathrm{s}} \\
\left(\mathrm{cm}^{3} \mathrm{~cm}^{-3}\right)\end{array}$ & $\begin{array}{c}K_{S} \\
\left(\mathrm{~mm} \mathrm{~s}^{-1}\right)\end{array}$ & $\begin{array}{c}S \\
\left(\mathrm{~mm} \mathrm{~s}^{-0.5}\right)\end{array}$ & $\begin{array}{c}\lambda_{C} \\
(\mathrm{~mm})\end{array}$ & $\begin{array}{c}\lambda_{m} \\
(\mathrm{~mm})\end{array}$ \\
\hline Natural & 12.64 & 2.64 & 0.24 & 0.033 & 0.344 & $5.38 \times 10^{-3}$ & 0.190 & 300.40 & 0.02 \\
Cultivated & 7.62 & 2.95 & 0.32 & 0.065 & 0.437 & $7.78 \times 10^{-2}$ & 0.349 & 4.07 & 1.80 \\
\hline
\end{tabular}

The bubbling pressure values obtained were $12.64 \mathrm{~cm}$ and $7.62 \mathrm{~cm}$ for natural soil and cultivated soil, respectively. The higher value indicates that greater pressure is needed to unsaturate the moisture and begin withdrawing water into the soil. In other words, the crop management techniques have modified the hydrodynamic characteristics of the soil, making the soil lose water more easily.

The natural soil presented a distribution index $(n)$ of 2.64 and the cultivated soil had an $n$ of 2.95. The higher the value, the lower the retention of water in the soil. As an example, for a matric potential of $0.42 \mathrm{~m}$, natural and cultured soils have a $\theta$ of $0.18 \mathrm{~cm}^{3} \mathrm{~cm}^{-3}$ and $0.12 \mathrm{~cm}^{3}$ $\mathrm{cm}^{-3}$, respectively. This parameter influences the hydraulic conductivity curve of the soil. For example, for $\theta=0.26 \mathrm{~cm}^{3} \mathrm{~cm}^{-3}$, the natural and cultivated soils had a $K(\theta)$ of $0.0002 \mathrm{~mm} \mathrm{~s}^{-1}$ and $0.0094 \mathrm{~mm} \mathrm{~s}^{-1}$, respectively.

The natural soil had a $\theta_{r}$ of $0.033 \mathrm{~cm}^{3} \mathrm{~cm}^{-3}$, about $50 \%$ of the value obtained for the cultivated soil, which was $0.065 \mathrm{~cm}^{3} \mathrm{~cm}^{-3}$. These values indicate that the natural soil allows water to be withdrawn from the soil by vegetation even when less water is available than in the cultivated soil.

The natural soil had a $\theta_{S}$ of $0.344 \mathrm{~cm}^{3} \mathrm{~cm}^{-3}$, about $80 \%$ of the value obtained for the cultivated soil, which was $0.437 \mathrm{~cm}^{3} \mathrm{~cm}^{-3}$. These values show that, for the same matric potential, the cultivated soil contains more water available to plants, a direct consequence of the management necessary for the crop that alters the soil porosity.

By fitting the equation proposed by Haverkamp (Equation 5) to the data obtained from the infiltration tests, it was possible to estimate the values for saturated hydraulic conductivity, sorptivity, capillary length scale, and the characteristic pore radius for both natural and cultivated soil. The values found for all parameters related to the natural soil were within the ranges determined by Oliveira Júnior et al. (2014), when comparing the hydrodynamic variability of soils with vegetation cover and with grass, in the semiarid region of Pernambuco.

The upper limit of the hydraulic conductivity curve is determined by $K_{S}$. This parameter was found to be different in the two soils studied. The natural soil had a $K_{S}$ of $5.38 \times 10^{-3} \mathrm{~mm} \mathrm{~s}^{-1}$, which was only about $7.5 \%$ of that obtained for cultivated soil, $7.78 \times 10^{-2} \mathrm{~mm} \mathrm{~s}^{-1}$. This provides evidence that the conduction of water in the natural soil is much less than in the anthropogenic soil. The values found are within the range determined by Leite et al. (2018), when studying the hydrodynamic behavior of the Caatinga in four different stages of degradation.

The capacity to absorb water as soon as it reaches the ground is represented by $S$. The natural soil presented an $S$ value of $0.190 \mathrm{~mm} \mathrm{~s}^{-0.5}$, about $54 \%$ of that obtained for cultivated soil, which was $0.349 \mathrm{~mm} \mathrm{~s}^{-0.5}$. That is, this property of the soil has been altered due to human action, which can change the ability of the natural soil to be reconstituted with the same original characteristics.

For natural soil, the values of $\lambda_{\mathrm{m}}$ and $\lambda_{C}$ were $0.02 \mathrm{~mm}$ and $300 \mathrm{~mm}$, respectively. These 
values indicate that, for natural soil, infiltration is governed by capillary forces with gravity having little effect. For cultivated soil, the behavior is the reverse. Infiltration is predominantly governed by gravity, while capillary action has little influence. The values found for $\lambda_{m}$ and $\lambda_{C}$ were $1.80 \mathrm{~mm}$ and $4.07 \mathrm{~mm}$. This demonstrates the importance of soil structure, as soils with the same texture can have very different hydraulic behaviors. As expected, the increase in the characteristic radius of the pores that effectively carry water implied an increase in $S$ and $K_{S}$.

Figure 3a shows the water retention curves of the natural and cultivated soils. It can be observed that, despite their similarities, the representative curve for natural soil presents extreme values different from those found for the cultivated soil. Probably due to soil management, which increased soil aeration. The inflection points are close, as evidenced by the values of $\left|h_{g}\right|$. As shown in the water retention curves for the soils, the hydraulic conductivity curves of natural and cultivated soils present similarities with greater differences at the extremes (Figure 3b). However, the maximum water conduction value for soil cultivated with forage palm is an order of magnitude greater than that determined for soil cultivated with natural vegetation. This causes rainwater to seep into the soil faster, increasing the possibility of soil erosion.
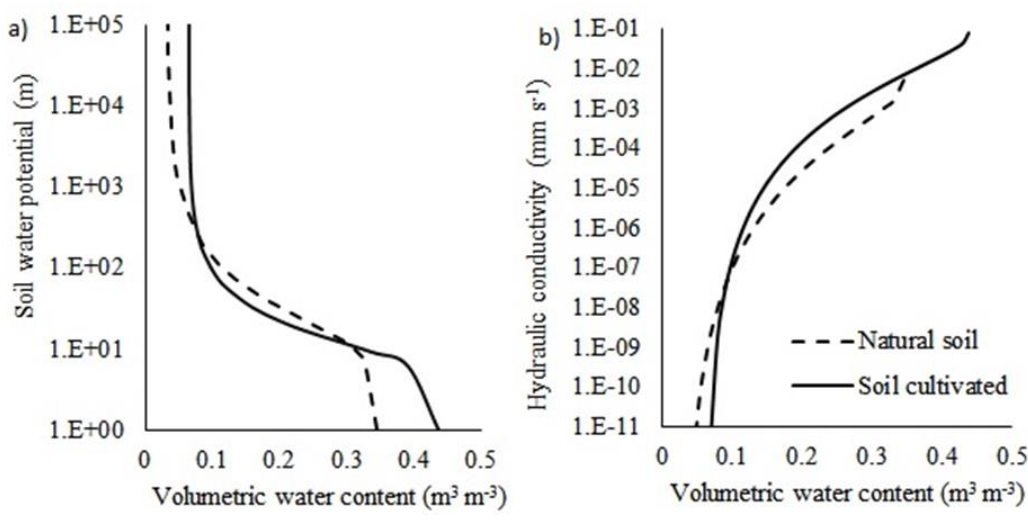

Figure 3. a) Water retention curves in natural and cultivated soils;

b) Hydraulic conductivity curves for natural and cultivated soils.

Although the differences in hydrodynamic characteristics appear to be small, they suggest an influence over the entire hydrological cycle at the locality. The natural soil presents characteristics that attenuate the infiltration and conduction of water into its interior, causing a greater surface runoff, characteristic of the region. With the replacement of the natural vegetation by the forage palm crop, a decrease in this flow occurs. These results agree with those found by Alaoui et al. (2011), who observed that surface runoff is controlled by saturated hydraulic conductivity and soil bulk density.

\section{CONCLUSIONS}

The adjustment of the Weibull equation proved to be appropriate, robust, and fully adapted to modeling the granulometric curves for the studied soils, allowing the methodology proposed by Arya and Heitman to be used to estimate the water retention curve for the soil.

The methodology proposed by Haverkamp provided acceptable values for the sorptivity and saturated hydraulic conductivity of the natural and cultivated soils, giving precise adjustments of accumulated infiltrations.

The differences in structure, especially in porosity, between the natural and cultivated soils control the hydrodynamic processes, resulting in alterations in the water retention curves and in hydraulic conductivity. 
The natural soil structure, characterized by relatively low values of $K_{S}$, presents an infiltrability that favors surface runoff.

Soil anthropization in the study area has promoted changes in the soil's physical attributes, decreasing its density and increasing porosity. Consequently, there is an increase in water infiltration into the soil and a reduction of runoff, corroborating results obtained in previous studies.

Conversion of forests to cropland is the main land-cover change in the Caatinga, and it has a major effect on soil hydraulic properties. Our study shows that a difference in infiltrability across the two sites is explained by a change in soil structure, arising from soil management.

\section{ACKNOWLEDGEMENTS}

The author would like to thank the Pernambuco State Foundation for Support of Science and Technology (FACEPE) for their financial support through research assistance (APQ 058201/15).

\section{REFERENCES}

ABNT. NBR 7181 - Solo: análise granulométrica. Método de ensaio. Rio de Janeiro, 2016. 12 p.

ALAOUI, A.; CADUFF, U.; GERKE, H. H.; WEINGARTNER, R. Preferential flow effects on infiltration and runoff in grassland and forest soils. Vadoze Zone Journal, n.10, p.367-377, 2011. http://dx.doi.org/10.2136/vzj2010.0076

ARYA, L. M.; HEITMAN, J. L. A non-empirical method for computing pore radii and soil water characteristics from particle-size distribution. Soil Science Society of American Journal, n. 6, p. 1537-1544, 2015. https://dx.doi.org/10.2136/sssaj2015.04.0145

EDIVANI, R. L.; FERNANDES, P. D.; CARNEIRO, M. S. S.; NEDER, D. G.; ARAUJO, J. S.; ANDRADE, A. P.; SOUTO FILHO, L. T. Acúmulo de biomassa e crescimento radicular da palma forrageira em diferentes épocas de colheita. Revista Acadêmica $\begin{array}{llllll}\text { Ciência Animal, } & \text { n. } & \text { 4, } & \end{array}$ https://dx.doi.org/10.7213/academico.011.004.AO04

FARRICK, K. K.; BRANFIREUN, B. A. Infiltration and soil water dynamics in a tropical dry forest: it may be dry but definitely not arid. Hydrological processes, n. 8, p. 4377-4387, 2014. http://dx.doi.org/10.1002/hyp.10177

GENIN, M.; ALIFRIQUI, M.; FAKHECH, A.; HAFDI, M.; OUAHMANE, L.; GENIN, D. Back to forests in pre-Saharan Morocco? When prickly pear cultivation and traditional agropastoralism reduction promote argan tree regeneration. Silva Fennica, n. 51, p. 122, 2017. https://dx.doi.org/10.14214/sf.1618

HAVERKAMP, R.; ROSS, P. J.; SMETTEM, K. R. J.; PARLANGE, J. Y. Three dimensional analysis of infiltration from the disc infiltrometer 2 . Physically based infiltration equation. $\begin{array}{llllll}\text { Water Resources Research, n.30, p. 2931-2935, } 1994 . & \end{array}$ http://doi.org/10.1029/94WR01788

KARGAS, G.; KERKIDES, P.; POULOVASSILIS, A. Infiltration of rainwater in semi-arid areas under three land surface treatments. Soil \& Tillage Research, n. 120, p. 15-24, 2012. https://dx.doi.org/10.1016/j.still.2012.01.004 
LEITE, A. M. P.; SOUZA, E. S.; SANTOS, E. S.; GOME, J. R.; CANTALICE, J. R.; WILCOX, B. P. The influence of forest regrowth on soil hydraulic properties and erosion in a semiarid region of Brazil. Ecohydrology, n. 11, p. 31-33, 2018. https://dx.doi.org/10.1002/eco.1910

LIMA, P. L. T.; SILVA, M. L. N.; QUINTON, J. N.; BATISTA, P. V. G.; CÂNDIDO, B. M.; CURI, N. Relationship among crop systems, soil cover, and water erosion on a Typic Hapludox. Revista Brasileira de Ciências do Solo, v. 42, p. 1-16, 2018. https://dx.doi.org/10.1590/18069657rbcs20170081

MENDONÇA, L. A. R.; VÁSQUEZ, M. A. N.; FEITOSA, J. V.; OLIVEIRA, J. F.; FRANCA, R. M.; VÁSQUEZ, E. M. F.; FRISCHKORN, H. Avaliação da capacidade de infiltração de solos submetidos a diferentes tipos de manejo. Engenharia Sanitária e Ambiental, n. 1, p. 89-98, 2009. https://dx.doi.org/10.1590/S1413-41522009000100010

OLIVEIRA JUNIOR, J. A. S.; SOUZA, E. S.; CORREA, M. M.; LIMA, J. R. S.; SOUZA, R. M. S.; SILVA FILHO, L. A. S. Variabilidade espacial de propriedades hidrodinâmicas de um Neossolo Regolítico sob pastagem e Caatinga. Revista Brasileira de Engenharia Agrícola e Ambiental, n. 6, p. 631-639, 2014. https://dx.doi.org/10.1590/S141543662014000600010

OLIVEIRA, D. B. C.; SOARES, W. A. Desempenho de modelos de infiltração tridimensional de água no solo. Revista Diálogos, n. 18, p. 519-544, 2017. http://dx.doi.org/10.13115/2236-1499v2n18p519

OWUOR, S. O.; BUTTERBACH-BAHL, K.; GUZHA, A. C.; RUFINO, M. C.; PELSTER, D. E.; DÍAZ-PINÉS, E.; BREUER, L. Groundwater recharge rates and surface runoff response to land use and land cover changes in semi-arid environments. Ecological Processes, n.16, p. 1-21, 2016. https://dx.doi.org/10.1186/s13717-016-0060-6

PHILIP, J. R. The quasi-linear analysis, the scattering analog, and other aspects of infiltration and seepage. In: FOK, Y.S. (Ed.). Infiltration development and application. Honolulu: Water Resources Research Center, 1987. p.1-27.

PINHEIRO, E. A. R.; COSTA, C. A. G.; ARAÚJO, J. C. Effective root depth of the Caatinga biome. Journal of Arid Environments, n. 89, p. 1-4, 2013. https://dx.doi.org/10.1016/j.jaridenv.2012.10.003

RODRIGUES, M. A.; SOUZA, C.; LIMA, D. D.; SILVA, S. D. P.; ALVES, D. C.; MACHADO, N. S. Impacto do cultivo do coqueiro irrigado na qualidade física do solo na região semiárida brasileira. Ciencia del suelo, n. 1, p. 139-144, 2016.

SOARES, W. A.; HAMMECKER, C. Comparison of Mathematical Models for the layout of Granulometric Curves of Brazilian Soils. Revista de Geografia, n. 1, p. 251-267, 2017.

SOARES, W. A. Análise da dinâmica da água em um solo não saturado sob condições de chuvas simuladas. Revista águas subterrâneas, n. 2, p. 200-209, 2018a. https://dx.doi.org/10.14295/ras.v32i2.29109

SOARES, W. A. Impact of spineless cactus cultivation (O. Ficus-indica) on the thermal characteristics of soil. Revista Ambiente \& Água, v. 13, n. 1, p. 1-12, 2018b. https://dx.doi.org/10.4136/ambi-agua.2148 
SOUZA, E. S.; ANTONINO, A. C. D.; NETTO, A. M.; SOUZA, R. M. S.; GONDIM, M. V. S.; LIMA, V. F.; LIMA, J. R. S.; ALVES, E. M.; COUTINHO, A. P.; SOARES, W. A. Hydrodynamic behavior of soils in recession agriculture in semiarid of Pernambuco State (Brazil). Journal of Environmental Analysis and Progress, n. 1, p. 52-60, 2016. https://dx.doi.org/10.24221/jeap.1.1.2016.984.52-60

VAN GENUCHTEN, M. Th. A closed-form equation for predicting the hydraulic conductivity of unsaturated soils. Soil Science Society of America Journal, n. 44, p. 892-898, 1980. https://dx.doi.org/10.2136/sssaj1980.03615995004400050002x

WHITE, I.; SULLY, M. J. Macroscopic and microscopic capillary length and time scales from field infiltration. Water Resources Research, v. 23, p. 1514-1522, 1987. https://doi.org/10.1029/WR023i008p01514 